\title{
$O$ tempo e o vento: notas \\ sobre a arte de burocratizar \\ DoI \\ http://dx.doi.org/10.11606/ \\ 2179-0892.ra.2017.132101 políticas de cotas na USP
}

\section{Ana Letícia de Fiori, Cibele Barbalho Assênsio, Fabiana de Andrade, Jacqueline Moraes Teixeira, Letizia Patriarca e Talita Lazarin Dal Bo}

- Universidade de São Paulo / São Paulo, SP, Brasil

、morgotia@gmail.com, cibele.assensio@gmail.com, fabiandrade79@yahoo.com.br, jamoteka@gmail.com,patr.letizia@gmail.com, talita.lazarin@gmail.com

\section{RESUMO}

Por que cotas na pós-graduação? Este texto enfrenta essa indagação apresentando uma descrição densa dos muitos trajetos burocráticos que a implementação de uma política de ações afirmativas mobiliza. Trata-se de um processo que acaba por produzir uma tensão quase que insustentável entre a temporalidade perdurável da burocracia versus os ventos necessários de mudança social que, nesse caso específico, demandam a transformação das tecnologias para a produção da ciência e para a abertura dos espaços reconhecidos de formulação dos saberes científicos. Para tanto, partimos da exposição do contexto e dos eventos referentes à formulação e tramitação de uma proposta de cotas no Programa de Pós-Craduação em Antropologia Social da Universidade de São Paulo (PPCAS/USP). Com isso, formulamos uma cartografia das políticas de cotas nos Programas de Pós-Craduação em Antropologia no Brasil, bem como uma reflexão acerca do lugar das políticas afirmativas dentro da conjuntura geral da USP. Por fim, apresentamos uma posição mais epistêmica acerca de como a abertura dos espaços de produção de conhecimento é fundamental para produzir instâncias plurais e democráticas na composição dos saberes antropológicos. 
Não digam que fui rebotalho, que vivi à margem da vida.

Digam que eu procurava trabalho,

Mas fui sempre preterida.

Digam ao povo brasileiro

Que meu sonho era ser escritora,

Mas eu não tinha dinheiro

Para pagar uma editora.

Carolina Maria de Jesus, Quarto de Despejo, 1960.

\section{COTAS NA PÓS-GRADUAÇÃo}

Por que cotas na pós-graduação? Esse questionamento ecoava sutilmente quando iniciamos em 2013 o debate sobre cotas no Programa de Pós-Craduação em Antropologia Social da Universidade de São Paulo (PPGAS/USP), ainda como comissão composta somente por estudantes de mestrado e doutorado. Nesse período, muitas unidades da USP realizavam uma ampla greve, questionando a falta de horizontalidade e a estrutura de poder anacrônica e autoritária da universidade, que impedia uma maior diversidade e paridade nos processos decisórios locais. Embora houvesse uma extensa pauta de greve, nós mestrandas/os e doutorandas/os decidimos paralisar nossas atividades acadêmicas e desenvolver uma proposta consistente e efetiva de cotas para nosso programa. O tema já era discutido na universidade pelo Núcleo de Consciência Negra (NCN) ${ }^{1}$ desde a década de 1980 e, mais recentemente, desde 2005, também pela Frente Pró-Cotas Raciais na USP². Ao longo do debate sobre cotas nos cursos de graduação da USP, a resistência contrária à sua implementação já estava pautada pela defesa da meritocracia e da manutenção de uma almejada excelência nos cursos. Não sem surpresa, encontramos argumentos semelhantes e resistências das mais diversas quando propusemos cotas na Pós-Graduação em Antropologia Social em 2013.

A preocupação com a manutenção da excelência científica também estava presente entre o corpo docente, que considerava os mecanismos do processo seletivo da pós-graduação uma garantia de parâmetros mínimos de qualidade entre discentes. Tais considerações, contudo, pouco indagavam sobre o quanto se impunha um regime de escassez de oportunidades de cursar a pós-graduação, que pouco tinha a ver com vocações e capacidades intelectuais. Tampouco, baseavam-se em dados sobre os impactos da criação de ações afirmativas em programas de pós-graduação. Eram, portanto, temores não embasados e pouco reflexivos. Por isso, iniciamos um levantamento extenso e consistente não somente das políticas afirmativas de cotas que existiam em outros Programas de Pós-Graduação em Antropologia nas universidades brasileiras, como estu-
1 Sobre o NCN, ver: http://www.ncn.org.br/ index.php/quem-somos. Acesso em 10 de março de 2017.

2 Sobre a Frente, ver: https://frenteprocotasraciaisusp. wordpress.com/sobre/.

Acesso em 10 de março de 2017. 
damos a fundo os critérios de avaliação da Coordenação de Aperfeiçoamento de Pessoal de Nível Superior (CAPES) e o Regimento da Pós-Graduação da USP. Organizamos diversos eventos, palestras e outras atividades com a finalidade de demonstrar que era possível desenvolvermos e implementarmos uma política de ações afirmativas, tais como cotas, em nosso programa.

Em cada atividade realizada, percebíamos a recorrência de argumentos contrários às cotas. Tais objeções indicavam: a preocupação de possíveis ações judiciais movidas por candidatas/os não cotistas contra o programa; o iminente prejuízo a uma suposta isonomia entre as/os candidatas/os no processo seletivo; a possível redução da qualidade do programa na avaliação da CAPES, devido à possibilidade de ampliação dos prazos para defesa e queda no aproveitamento das/os estudantes; e a defesa da meritocracia por parte de algumas/ns docentes, que discordavam que estudantes com melhores notas fossem excluídas/os da lista final de classificação. Ou seja, tornou-se perceptível que muitos dos temores em relação à implementação de cotas no PPCAS eram oriundos de mecanismos de controle e restrição externos ao programa e às agendas de produção de conhecimento antropológico, pois emergiam de um quadro de crescente judicialização de conflitos (incluindo os universitários) e de uma maior dependência departamental de critérios de avaliação das agências de fomento pautados por lógicas quantitativistas e produtivistas, muitas vezes pouco compatíveis com os modos de produzir conhecimento antropológico.

Entretanto, à época percebemos que uma série de Programas de Pós-Craduação em Antropologia Social (PPCAS) já havia iniciado políticas de cotas nos processos seletivos de ingresso. Embora muito variadas em termos de proporção, reserva de vagas, criação de vagas ou porcentagem garantida de pessoas optantes em cada etapa do processo seletivo, encontramos com entusiasmo a existência de políticas afirmativas nos PPCAS da UFAM, do Museu Nacional/UFR], da UFPA e da UFSC, e, em vias de implementação, na UnB (ver quadro na página 60).

Em uma ampla plenária, realizada em novembro de 2013, apresentamos pela primeira vez nossa proposta de cotas a docentes, discentes e funcionárias/ os do PPCAS/USP, que pôde ser amplamente debatida. Ao final, concluímos que uma política de cotas era possível e só dependia de nós. Assim, a plenária deu origem a uma comissão tripartite, entre discentes, docentes e funcionárias/os ${ }^{3}$. Esta comissão prosseguiu enfrentando a burocracia universitária e as resistências internas oferecidas nas muitas instâncias que nossa proposta percorreu ao longo do trâmite do processo, algumas das quais ainda persistem.

Conforme o trabalho se adensou, ficou cada vez mais evidente para a comissão que, para responder à pergunta "por que cotas na pós-graduação?", precisaríamos de uma proposta consistente sobre o que queríamos com e para a pós-graduação. Assim, deveríamos reformular a pergunta para: "por que cotas

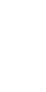


e para qual universidade?". Considerávamos a possibilidade de interferir no tradicional e conhecido elitismo universitário, manifesto, na USP, na resistência a uma política efetiva de cotas e na aplicação de políticas de bônus que se mostraram ineficazes para mudar o perfil dos ingressantes. Inserir a pós-graduação na agenda política de debates e propostas parecia começar uma reforma pelo teto, ou quase. E por que não?

Levantamos um extenso material sobre as experiências de outros programas e sobre os critérios de avaliação da CAPES, assim como um profundo estudo sobre as possibilidades de mudanças internas ao PPCAS dentro do Regimento de Pós-Graduação da USP. Tais esforços deixavam evidentes duas facetas da pós-graduação que precisavam ser rompidas. De um lado, o caráter elitista dos cursos de pós-graduação que esperam receber estudantes fluentes em línguas estrangeiras, prioritariamente o francês e o inglês. Muitas/os docentes, por exemplo, viam com preocupação a retirada das provas de línguas durante os processos seletivos. De outro, a exigência de um perfil específico de mestrandas/os e doutorandas/os apoiado na formação acadêmica em universidades tidas como de excelência, não por acaso situadas na região Sul-Sudeste do país, dificultava a participação de estudantes com outras experiências e formações universitárias, principalmente pelo formato da prova para ingresso. Embora o caráter endógamo do PPCAS/USP esteja pouco a pouco se transformando, com a vinda de estudantes de outros cursos e outros programas de pós-graduação, a mudança de perfil do corpo discente ainda é lenta, mantendo-se majoritariamente paulista ou da região Sul-Sudeste, branco, de classe média e cisgênero ${ }^{4}$. Os gráficos abaixo foram produzidos com dados do Sistema Janus de gerenciamento da pós-graduação na USP. Referem-se à diversidade institucional, pois não há informações étnico-raciais coletadas pelo sistema.
4 Pessoas cisgênero são aquelas que vivenciam seu gênero igual ao sexo que lhes foi atribuído em seu nascimento.

\section{Diversidade institucional - Mestrado PPGAS/USP}

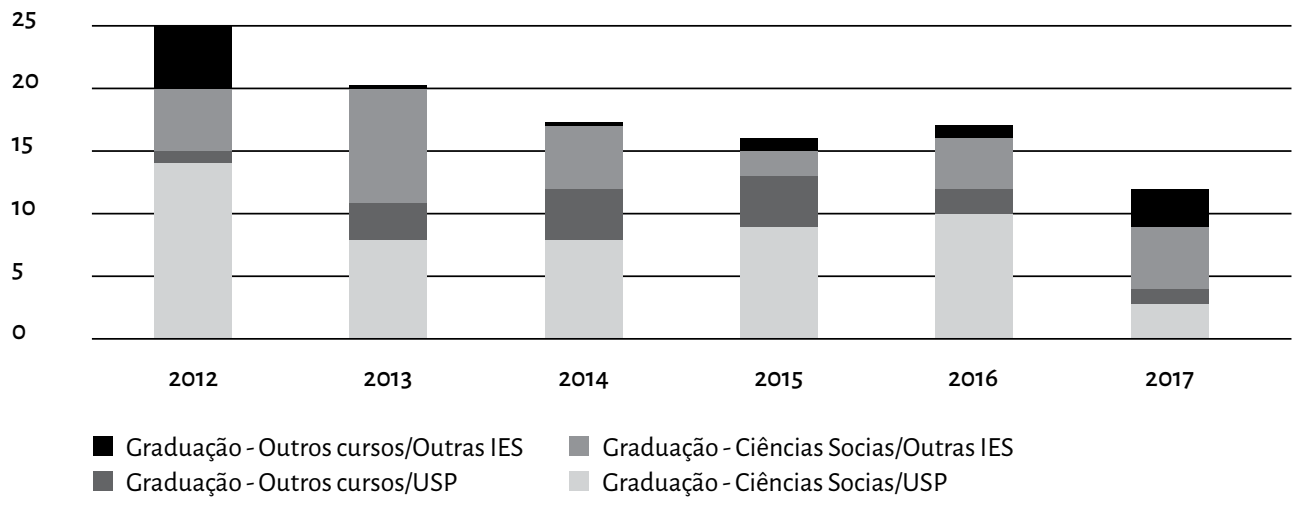




\section{Diversidade institucional - Doutorado PPGAS/USP (Graduação)}

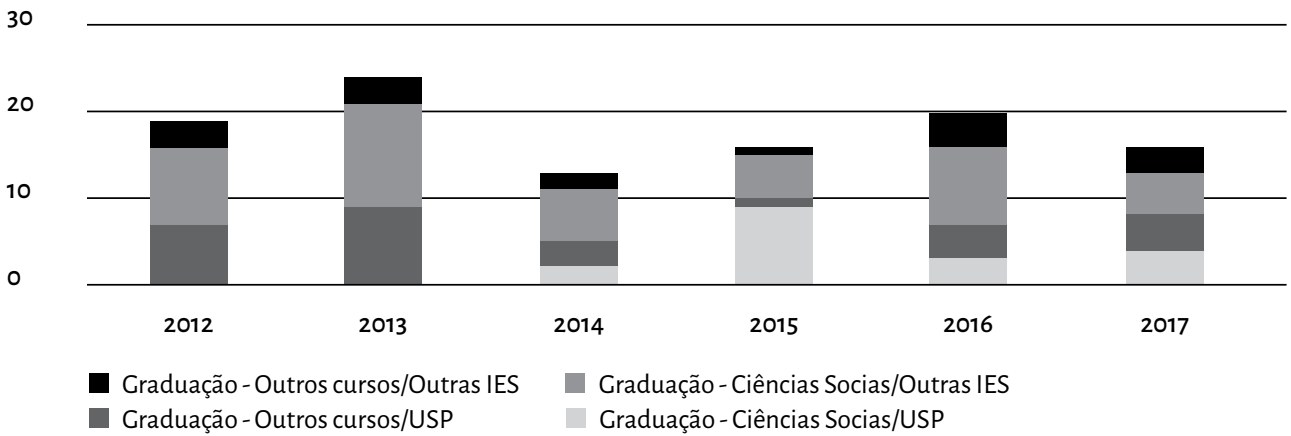

\section{Diversidade institucional - Doutorado PPGAS/USP (Mestrado)}

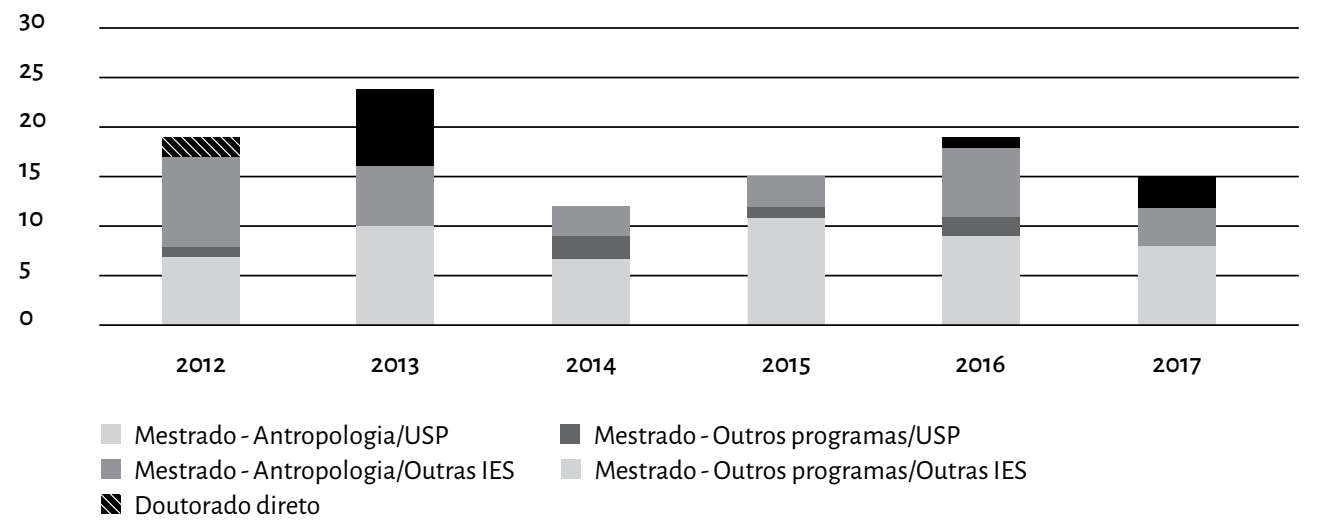

Cada vez ficava mais evidente que estávamos propondo outras maneiras de entender a produção de conhecimento e, nesse processo, também estávamos buscando repensar o caráter do próprio Programa. A antropologia, habituada a refletir sobre outras formas de estar no mundo, outras cosmologias e saberes, encontrava ainda alguma resistência em reconhecê-las como também produtoras de conhecimento de valor científico e etnográfico. A política de cotas permitiria, entretanto, que o PPCAS produzisse teses e dissertações com questões suscitadas a partir de múltiplas visões e experiências no mundo, seja com o ingresso de negras/os, indígenas ou pessoas com deficiência5. "Por que cotas na pós-graduação?" transmutava-se em "por que não cotas na pós-graduação?".

5 Ao final do texto apresentamos as discussões acerca de identidades políticas que, no momento da elaboração de nossa proposta em 2013, ainda não estavam consolidadas, mas ganham impulso renovado sobretudo com a notícia dos processos seletivos nos cursos de pósgraduação da UFBA (2017) que criam vagas adicionais também para pessoas trans e quilombolas. Ver: https:// www.ufba.br/noticias/sistemade-cotas-na-p\% $\mathrm{C}_{3} \% \mathrm{~B} 3 \mathrm{~s}$ gradua $\% \mathrm{C}_{3} \% \mathrm{~A} 7 \% \mathrm{C}_{3} \% \mathrm{~A} 30-$ $\% \mathrm{C}_{3} \% \mathrm{~A}$-/aprovado-na-ufba, último acesso em 17/02/2017. 
A defesa da meritocracia oblitera a potência que outros saberes e outras formas de estar no mundo trariam à produção acadêmica, e que já têm reconhecimento em outros programas.

Atualmente, segundo dados da CAPES, existe cerca de 21 cursos de Mestrado e 14 cursos de Doutorado em Antropologia no Brasil, sem contar aqueles que funcionam conjuntamente com os de Arqueologia, Sociologia e Ciência Política. Embora nosso levantamento não tenha sido completamente exaustivo, sabemos que hoje existem 9 PPGAS com políticas de cotas já implementadas em seus editais para o ingresso de estudantes autodeclaradas/os pretas/os, pardas/ os e indígenas, sendo que 5 deles também possuem cotas para pessoas com deficiência. Destes, 3 possuem nota 7 na avaliação trienal de 2013 da CAPES (MN/ UFR], UnB e UFRCS) e um com nota 6 (Unicamp). No quadro abaixo podemos observar um breve levantamento das políticas afirmativas adotadas pelos PPGAS no Brasil:

\section{Breve levantamento: Políticas Afirmativas em Programas de Pós-Graduação em Antropologia no Brasil [2017]}

\begin{tabular}{|c|c|c|c|c|c|c|}
\hline $\begin{array}{l}\text { PROGRAMAS } \\
\text { (PPGAS) }\end{array}$ & NEGROS & INDÍGENAS & $\begin{array}{l}\text { PESSOAS COM } \\
\text { DEFICIÊNCIA }\end{array}$ & QUILOMBOLAS & $\begin{array}{l}\text { PESSOAS } \\
\text { TRANS }\end{array}$ & $\begin{array}{l}\text { ANO DE } \\
\text { INGRESSO DA } \\
\text { PRIMEIRA } \\
\text { TURMA }\end{array}$ \\
\hline UFAM & $\begin{array}{l}\text { Oferecimento de } 5 \text { (ci } \\
\text { suplementares no Me } \\
\text { (três) no Doutorado }\end{array}$ & $\begin{array}{l}\text { nco) vagas } \\
\text { strado e } 3\end{array}$ & . & . & . & $\begin{array}{l}\text { Indígenas } \\
\text { (2011) e } \\
\text { Indígenas e } \\
\text { Negros (2016) }\end{array}$ \\
\hline UFPA & $\begin{array}{l}\text { Reserva de } 9 \text { (nove) } \\
\text { vagas especiais, } \\
\text { mantidas caso não } \\
\text { sejam preenchidas }\end{array}$ & $\begin{array}{l}\text { Destina } 1 \text { (uma) } \\
\text { vaga suplementar, } \\
\text { extinta caso não seja } \\
\text { preenchida }\end{array}$ & . & . & . & 2012 \\
\hline $\begin{array}{l}\text { Museu } \\
\text { Nacional/ } \\
\text { UFRJ }\end{array}$ & $\begin{array}{l}\text { Reserva de } 9 \text { (nove) } \\
\text { vagas especiais, } \\
\text { mantidas caso não } \\
\text { sejam preenchidas }\end{array}$ & $\begin{array}{l}\text { Destina } 1 \text { (uma) } \\
\text { vaga suplementar, } \\
\text { extinta caso não seja } \\
\text { preenchida }\end{array}$ & . & . & . & 2013 \\
\hline UFSC & $\begin{array}{l}\text { Reserva de } 20 \% \text { de } \\
\text { vagas no Mestrado e } \\
20 \% \text { no Doutorado }\end{array}$ & $\begin{array}{l}\text { Mínimo de } 1 \text { (uma) } \\
\text { vaga no Mestrado } \\
\text { e } 1 \text { (uma) vaga no } \\
\text { Doutorado }\end{array}$ & . & . & . & 2013 \\
\hline
\end{tabular}


Dossı|̂́ | Ana Letícia de Fiori, Cibele Barbalho Assênsio, Fabiana de Andrade, Jacqueline Moraes Teixeira, Letizia Patriarca e Talita Lazarin Dal Bo |O tempo e o vento: notas

sobre a arte de burocratizar políticas de cotas na USP

\begin{tabular}{|c|c|c|c|c|c|c|}
\hline $\begin{array}{l}\text { PROGRAMAS } \\
\text { (PPGAS) }\end{array}$ & NEGROS & INDÍGENAS & $\begin{array}{l}\text { PESSOAS COM } \\
\text { DEFICIÊNCIA }\end{array}$ & QUILOMBOLAS & $\begin{array}{l}\text { PESSOAS } \\
\text { TRANS }\end{array}$ & $\begin{array}{l}\text { ANODE } \\
\text { INGRESSO DA } \\
\text { PRIMEIRA } \\
\text { TURMA }\end{array}$ \\
\hline
\end{tabular}

UFG

\begin{tabular}{lll}
\hline UnB & Destina $20 \%$ das & Destina 1 (uma) \\
vagas no Mestrado e & vaga no mestrado \\
$20 \%$ no Doutorado & e 2 (duas) no \\
& Doutorado
\end{tabular}

\begin{tabular}{|c|c|c|c|c|c|c|}
\hline Unicamp & $\begin{array}{l}\text { Adicional de até } \\
3 \text { (três) vagas no } \\
\text { Mestrado e até } 2 \\
\text { (duas) no Doutorado }\end{array}$ & $\begin{array}{l}\text { Disponibiliza } 2 \\
\text { (duas) vagas } \\
\text { (Mestrado e } \\
\text { Doutorado) }\end{array}$ & . & . & . & 2016 \\
\hline UFRGS & $\begin{array}{l}\text { Reserva de } 4 \\
\text { (quatro) vagas }\end{array}$ & $\begin{array}{l}\text { Destina } 2 \\
\text { (duas) vagas } \\
\text { suplementares }\end{array}$ & $\begin{array}{l}\text { Destina } 2 \\
\text { (duas) vagas } \\
\text { suplementares }\end{array}$ & . & . & 2016 \\
\hline UFBA & Destina 1 (uma) vaga & suplementar & $\begin{array}{l}\text { Destina } 1 \\
\text { (uma) vaga } \\
\text { suplementar }\end{array}$ & $\begin{array}{l}\text { Destina } 1 \\
\text { (uma) vaga } \\
\text { suplementar }\end{array}$ & $\begin{array}{l}\text { Destina } 1 \\
\text { (uma) vaga } \\
\text { suplementar }\end{array}$ & 2017 \\
\hline UFMG & $\begin{array}{l}3 \text { (Três) vagas } \\
\text { (Mestrado e } \\
\text { Doutorado) }\end{array}$ & $\begin{array}{l}2 \text { (Duas) vagas } \\
\text { no Mestrado e } 1 \\
\text { (uma) vaga no } \\
\text { Doutorado }\end{array}$ & $\begin{array}{l}\text { Destina } 1 \\
\text { (uma) vaga }\end{array}$ & . & . & 2017 \\
\hline USP & $\begin{array}{l}\text { Reserva de } 20 \% \text { de } \\
\text { vagas no Mestrado e } \\
20 \% \text { no Doutorado } \\
\text { em cada fase }\end{array}$ & $\begin{array}{l}\text { Criação de } 2 \\
\text { (duas) vagas } \\
\text { (Mestrado e } \\
\text { Doutorado) }\end{array}$ & $\begin{array}{l}\text { Reserva de } 5 \% \text { para } \\
\text { mestrado e } 5 \% \text { para } \\
\text { doutorado }\end{array}$ & . & . & $\begin{array}{l}\text { Em } \\
\text { Trâmite }\end{array}$ \\
\hline UFSCAR & Em Trâmite & $\begin{array}{l}\text { Em } \\
\text { Trâmite }\end{array}$ & Em Trâmite & . & . & $\begin{array}{l}\text { Em } \\
\text { Trâmite }\end{array}$ \\
\hline
\end{tabular}

Fonte: Consulta a Editais e Resoluções disponibilizadas online pelos Programas de Pós-Graduação em Antropologia. Consulta realizada entre janeiro e fevereiro de 2017.

Esses dados demonstram que realizar uma política de cotas na universidade pública não alterará a avaliação sistemática feita pela CAPES. Ao contrário, reforçam que essa é uma proposta que pretende não somente incluir pessoas negras, indígenas e pessoas com deficiência na produção de conhecimento, mas que essas pessoas são parte fundamental para construir outros olhares, mais plurais, e romper com a estrutura elitista e meritocrática das universidades públicas. 
Esta valorização da diversidade na produção do conhecimento, na eleição de temas de pesquisa e na formação de pesquisadoras/es não é exclusividade das Humanidades. Ao iniciarmos o debate no PPCAS/USP em 2013, fomos procuradas, e até hoje somos, por estudantes de programas das áreas de Exatas e Biológicas, como do Instituto de Física, Instituto de Ciências Biológicas, Escola Politécnica, Faculdade de Saúde Pública, entre outros, que nos solicitaram informação e participação em debates. A crítica às velhas e desgastadas estruturas universitárias e da pesquisa acadêmica em nossa universidade espraiou-se por outras unidades.

\section{POR QUE A USP NÃO TEM COTAS?}

Antes de apresentarmos de maneira mais detalhada a trajetória política e institucional de nossa proposta de cotas, é necessário contextualizar um pouco as políticas afirmativas adotadas pela USP para a graduação.

"Por que a USP não tem cotas?" consiste em um movimento recente, iniciado durante o período de greve do ano de 2016, que reuniu estudantes e membros de coletivos que militam por cotas na universidade, tais como o Núcleo de Consciência Negra (NCN), atuante na USP desde 1987, e o coletivo Ocupação Preta ${ }^{6}$, criado em 2015. Impulsionado pela interpelação do título, o movimento buscou reunir documentos, dados e uma grande corrente de apoio público ${ }^{7}$ ao projeto de cotas para os cursos de graduação desenvolvido pelo coletivo Frente Pró-Cotas Raciais da USP. Ampliar o debate sobre cotas na universidade era, sobretudo, uma forma de pressionar para que a maior instância deliberativa da USP, o Conselho Universitário (CO), discutisse e aprovasse o projeto .

Por que, dentre o conjunto variado de ações afirmativas, optar por cotas? As medidas propostas e implementadas até o presente para os cursos de graduação na USP não eram cotas, e se mostraram ineficazes. Desde 2006, a USP possui o Programa de Inclusão Social (INCLUSP) que concede bônus de pontuação no vestibular promovido pela FUVEST. Estes bônus eram de até $15 \%$ da nota da primeira fase do processo para pessoas que cursaram o Ensino Médio em escolas públicas, uma pontuação adicional de $5 \%$ para quem estivesse prestando o vestibular pela segunda ou terceira vez, e $5 \%$ de bonificação específica a pessoas autodeclaradas pretas, pardas e indígenas.

Em 2012, a promulgação da Lei Federal 12.711 (alterada pela Lei Federal 13.409/2016), conhecida como Lei de Cotas, demonstrava o descompasso entre o perfil das pessoas ingressantes na universidade e as porcentagens de representatividade populacional exigidas pela lei'. Neste ano de 2017, na USP, das 10.733 vagas oferecidas, apenas 793 foram ocupadas por pessoas autodeclaradas pretas, pardas e indígenas, correspondendo a apenas $7 \%$. Tal valor está bastante
6 Composto por jovens negras e negros, promove performances teatrais em espaços de convivência comum no campus e intervenções políticas em salas de aula, auditórios e eventos. Ver: https://pt-br.facebook. com/Ocupa\% $\mathrm{C}_{3} \% \mathrm{~A} 7 \% \mathrm{C}_{3} \% \mathrm{~A} 30-$ Preta-352926291570552/, acesso em 10 de março de 2017.

7 Como parte do conjunto de manifestações organizadas pelo "Por que a USP não tem cotas?" foi criada uma petição pública que pretende coletar quatorze mil assinaturas, disponível em: http:// www.cotasnausp.minhasampa.org br/, acesso em 10 de março de 2017

8 A proposta de Resolução Normativa que cria o "Programa de Ações Afirmativas" (PAAUSP), construída pela Frente Pró-Cotas Raciais da USP, designa 50\% das vagas em cursos de graduação para estudantes procedentes de escolas públicas, adotando o mesmo critério de reserva de vagas aprovado pelo Congresso Nacional e pelo Senado Federal no Projeto de Lei 180/2008, que posteriormente foi também assumido pela Lei $12.711 / 2012$, conhecida como Lei de Cotas. Disponível em: https:// frenteprocotasraciaisusp.files. wordpress.com/2012/08/propostade-resolucза7сзазо1.pdf, acesso em 14/02/2017.

\section{Dispõe sobre a}

obrigatoriedade das instituições federais de Educação Superior reservarem no mínimo 50\% de vagas nos cursos de graduação para estudantes que tenham cursado o Ensino Médio em escolas públicas, sendo que parte delas deve ser preenchida por estudantes autodeclaradas/os pretas/os, pardas/os e indígenas e pessoas com deficiência, em proporção ao total de vagas no mínimo igual à da população da unidade da Federação onde está instalada a instituição, segundo o último censo do IBCE. Disponível em: http:// www.planalto.gov.br/CCIVIL_03/_ Ato2011-2014/2012/Lei/L12711.htm, acesso em 14/02/2017. 
aquém da proporção populacional de pessoas autodeclaradas pretas, pardas e indígenas no Estado de São Paulo, aproximadamente 35\%.

Esse cenário impeliu o Governo do Estado de São Paulo a criar o PIMESP (Programa de Inclusão por Mérito no Ensino Superior Público Paulista), que insistia na expansão dos mecanismos de acesso através de bonificação para egressas/os de escolas públicas e pessoas pretas, pardas e indígenas, propondo também um sistema de ensino preparatório à distância como pré-requisito para concorrer às vagas nos cursos de graduação. Como as demais propostas de inclusão, o PIMESP também negligenciou a discussão sobre cotas desenvolvida no âmbito da universidade, e tampouco reconheceu a experiência de outras instituições de Ensino Superior que implementaram políticas de cotas há mais de uma década. Em decorrência de manifestações contrárias a essa nova proposta, mobilizadas por organizações estudantis e coletivos de luta pela igualdade racial, como o NCN, o PIMESP não foi implementado, e os anos de 2013 a 2015 seguiram sem qualquer medida institucional para diminuir a desigualdade de acesso à universidade e reparar o desequilíbrio étnico-racial de estudantes matriculadas/os. A despeito disso, nos anos de $2014^{10}$ e $2015^{11}$, a USP passou a exibir e comemorar uma pequena progressão no aumento da porcentagem de ingressantes egressas/os de escolas públicas, que ampliou de $28 \%$ para $32 \%$, e no total de pessoas autodeclaradas pretas, pardas e indígenas, que passou de $7 \%$ para $9 \%$; índices, contudo, bem distantes dos salvaguardados pela Lei de Cotas.

No processo seletivo de 2015, o INCLUSP contou com 39.915 pessoas inscritas, $2,8 \%$ a mais que o total de inscritas no ano anterior. Destas, apenas 3.811 foram aprovadas, totalizando 9,55\% da integralidade de inscritas egressas de escolas públicas. Entre as pessoas autodeclaradas pretas, pardas e indígenas, o número de inscritas no INCLUSP foi de 11.202, e o índice de aprovação foi de 8,06\%.

Em 2016, o reconhecimento constitucional das cotas como tecnologia eficaz para a ampliação de acesso ao Ensino Superior público e a discrepância do perfil de ingressantes no Estado de São Paulo fizeram com que a USP aprovasse o oferecimento de $30 \%$ de suas vagas anuais via SISU (Sistema de Seleção Unificada - criado em 2010 pelo Ministério da Educação), que indexa e oferta vagas em instituições de Ensino Superior, considerando a média obtida no Exame Nacional do Ensino Médio (ENEM).

Ao adotar-se parcialmente o SISU - posto que as carreiras mais concorridas não o fizeram - houve um aumento significativo do número de pessoas inscritas provenientes de escolas públicas, bem como de pessoas autodeclaradas pretas, pardas e indígenas. Contudo, o modo como o SISU foi adotado gerou um novo processo de exclusão, pois ao ser mantida uma nota mínima para aprovação no processo seletivo superior à nota de corte do restante das vagas gerenciadas pela FUVEST, o número de pessoas egressas de escolas públicas matriculadas caiu consideravelmente ${ }^{12}$.
10 Disponível em: https://www.usp.br/impren$\mathrm{sa} / \mathrm{p}=40301$, acesso em $10 \mathrm{de}$ março de 2017.

11 Disponível em: https://www.usp.br/imprensa/?p=48641, acesso em 10 de março de 2017

12 Disponível em: http:// www1.folha.uol.com.br/ educacao/2016/07/1789632-cai-numero-de-alunos-que-entram-na-usp-com-bonus-da-rede-publica.shtml, acesso em 10 de março de 2017 
Segundo os dados disponibilizados pela própria universidade, é possível perceber um acréscimo de 3,62\% no total de inscritas/os, e um acréscimo de 7,74\% de inscritas/os autodeclaradas/os pretos, pardos e indígenas no INCLUSP em relação ao ano anterior. Apesar deste aumento na inscrição, houve queda no índice de aprovação das/os inscritas/os no INCLUSP, algo que entre as pessoas autodeclaradas pretas, pardas e indígenas foi de $19,26 \%$, como demonstra o gráfico a seguir:

Pessoas pretas, pardas, indígenas: incritas versus matriculadas $\quad$ a $2015 \quad \square 016$

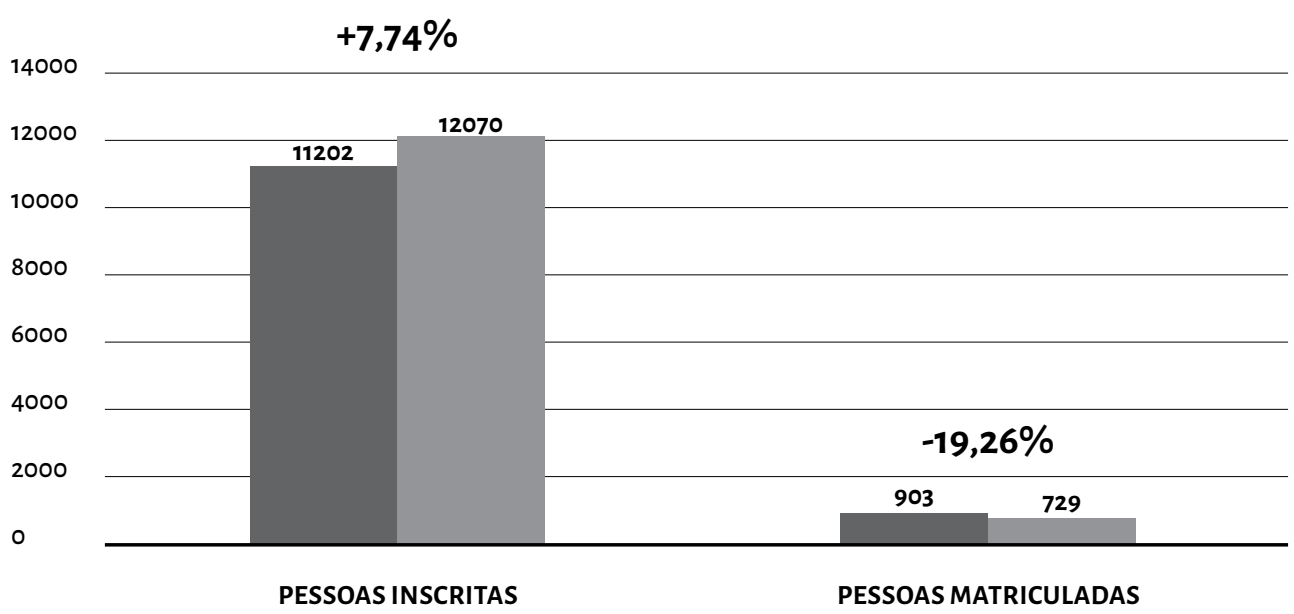

Fonte: www1.folha.uol.com.br/educacao/2016/07/1789632-cai-numero-de-alunos-que-entram-na-usp-com-bonus-darede-publica.shtml, acesso em 10 de março de 2017

A redução do índice de aprovação entre as pessoas inscritas no INCLUSP, por intermédio da inclusão do SISU no processo de ingresso na USP, resultou na consequente retração do número de pessoas matriculadas que se autodeclararam pretas, pardas e indígenas em relação ao ano de 2014, como é possível ver nos gráficos abaixo':

13 Agradecemos Duda Galhardo (Ciências Sociais USP) pelo auxílio com os dados estatísticos e pela produção dos gráficos.

\section{Perfil racial de estudantes matriculadas/os provenientes de escolas públicas em 2014 \\ - pessoas brancas e amarelas \\ pessoas pretas, parfdas e indígenas \\ Fonte: https://www.usp.br/imprensa/ ?p=40301, acesso em 10 de março de 2017}

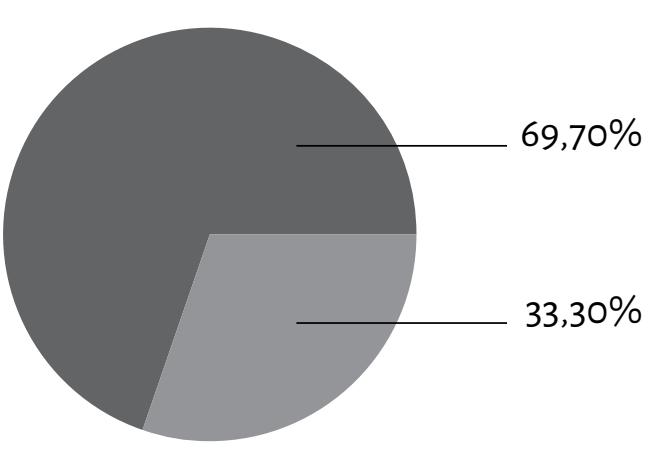




\section{Perfil racial de estudantes matriculadas/os provenientes de escolas públicas em 2016}

pessoas brancas e amarelas

pessoas pretas, pardas e indígenas

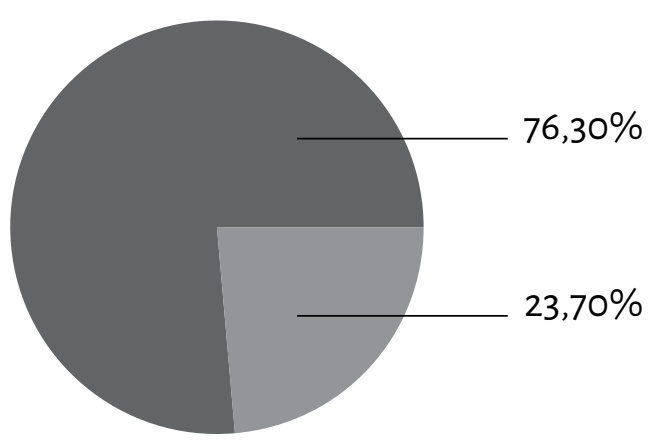

Fonte: www1.folha.uol.com.br/educacao/2016/07/1789632-cai-numero-de-alunos-que-entram -na-usp-com-bonus-darede-publica.shtml, acesso em 10 de março de 2017.

A partir do que foi apresentado até aqui, é possível concluir que os dez anos de execução de uma política afirmativa de bônus para ingresso nos cursos de graduação demonstrou pouca eficácia diante da necessidade de produção de tecnologias de ampliação do acesso à universidade, suscitando a urgência de se implementar uma política de cotas.

\section{OS MUITOS TRAJETOS DE UMA PROPOSTA}

O panorama apresentado acima contribui para o entendimento de quão engessadas são as estruturas de poder da Universidade de São Paulo, o que acaba por testificar a existência de inúmeros obstáculos de acesso e produção de conhecimento por parte de segmentos historicamente excluídos de laboratórios, salas de aula, bibliotecas, museus etc. Tal processo encontra seu esteio na pós-graduação, espaço constituído por excelência para o mérito, para a produtividade e para a diferenciação.

Como assinalado anteriormente, a proposta de uma política de cotas no PPGAS da USP começou a ser discutida em 2013, durante as atividades de greve, a partir da iniciativa do corpo discente de repercutir as pautas debatidas pelo movimento de greve no âmbito da pós-graduação. Além de exímia pesquisa acerca do processo de implementação de ações afirmativas por parte de outros Programas de Pós-Craduação, foi necessário examinar o complexo e fragmentado sistema de normas para a pós-graduação da USP, fundamentado por três documentos de dimensões e instâncias distintas. O primeiro e mais importante deles é o Regimento de Pós-Craduação, que havia passado por um processo intenso de negociação e discussão, que atravessou ao menos dois anos de greves ${ }^{14}$. Os outros dois documentos incluíam as regras das instâncias locais, um da Faculdade de Filosofia, Letras e Ciências Humanas (FFLCH) e outro com as normas de funcio-
14 A Reforma do Regimento de Pós-Graduação havia sido aprovada em 18 de abril de 2013, uma de suas novidades é uma ideia de "autonomia" de funcionamento e gestão dos Programas em relação a Pró Reitoria de Pós Graduação da USP. Disponível em: http://www.leginf.usp. $\mathrm{br} /$ ?resolucao=resolucao-no6542-de-18-de-abril-de-2013, acesso em 10 de março de 2017. 
namento do PPCAS. Segundo essa enrijecida cadeia institucional, a proposta elaborada precisaria ser aprovada primeiramente pelas duas instâncias locais, Comissão Coordenadora do Programa (CCP) e Conselho de Pós-Graduação (CPG), e posteriormente encaminhada para a Pró-Reitoria de Pós-Graduação, onde seria avaliada pela assessoria jurídica da Câmara de Normas e Recursos (CnR).

Com a comissão formada e o documento redigido, a primeira sessão de apresentação à CCP, composta por docentes do PPCAS e representantes discentes, ocorreu ainda em dezembro de 2013. Alguns ajustes ao documento foram propostos, bem como o pedido de maior aprofundamento da inclusão de pessoas com deficiência na política de reserva de vagas.

Em 2014, o documento voltou a ser discutido em reuniões da CCP, com o intuito de formular e fortalecer na proposta mecanismos de acompanhamento e políticas de permanência para pessoas optantes. O projeto, mais maduro, foi aprovado por unanimidade em agosto de $2014 \mathrm{e}$, seguindo as regras de tramitação estabelecidas pelo Regimento de Pós-Graduação, foi encaminhado à instância seguinte, a CPG, colegiado que reúne coordenadoras/es de todos os Programas de Pós-Craduação da FFLCH. Seguindo recomendações da presidência da CPG, o projeto precisaria receber pareceres favoráveis ou contrários das demais CCPs da FFLCH, o que nos levou a visitar cada um dos 26 Programas de Pós-Craduação para apresentar a proposta, acompanhar a discussão e, por fim, realizar uma votação. Ao final desta árdua etapa de debates, no dia 15 de dezembro de 2014 , a proposta foi aprovada por unanimidade pela CPG. Porém, antes de ser encaminhada para a Câmara de Normas e Recursos (CnR) como recomenda o Regimento, a presidência da CPC indicou-nos que a proposta precisaria ser votada pela Congregação da FFLCH, colegiado administrativo composto por 69 docentes, representantes de funcionárias/os e representantes discentes, que reúne todos os departamentos e cursos da Faculdade.

Novo parecer e nova apresentação nos foram solicitados, até que no dia 25 de março de 2015 a proposta foi aprovada com unanimidade pela Congregação da Faculdade e, após a homologação da votação, encaminhada para a Câmara de Normas e Recursos (CnR), acompanhada de pareceres jurídicos externos à Universidade de São Paulo. Estes pareceres foram emitidos por membros do Ministério Público do Estado de São Paulo, da Defensoria Pública do Estado de São Paulo e da Organização das Nações Unidas. Foram anexados também pareceres internos circunstanciados e idôneos, emitidos por docentes indicados respectivamente pelo Presidente (no caso da CPG) e pelo Diretor (no caso da Congregação) da FFLCH.

Sem apresentar qualquer objeção jurídica ao seu teor, a Câmara de Normas e Recursos (CnR) encaminhou no dia 25 de maio de 2015 um pedido para o gabinete da Reitoria solicitando-Ihe "resposta institucional". Este encaminhamento 
contraria os procedimentos regimentais previstos, segundo os quais compete à CnR deliberar sobre "os regulamentos e normas dos Programas e suas eventuais alterações" (artigo 19; § I do Regimento de Pós-Graduação da USP), em conformidade com as diretrizes de autonomia e gestão atribuídas aos Programas de Pós-Craduação da Universidade previstas no Artigo 37 do referido Regimento ${ }^{15}$. O pedido de reformulação das Normas e Regras de ingresso no PPCAS transcorreu nas instâncias para avaliação e votação da USP por 24 meses, permanecendo sete deles sob a guarda da Reitoria. Contudo, o processo foi arquivado arbitrariamente em 21 de dezembro de 2015: "até nova provocação".

Além de contrariar normas do Regimento de Pós-Craduação da Universidade que não prevê em nenhum de seus artigos a intervenção da Reitoria, outrossim, imputa a gestão da Pós-Graduação à Pró-Reitoria de Pós-Craduação, a decisão arbitrária de arquivamento do processo deslegitima a aprovação de inúmeros colegiados e instâncias institucionais. Este arquivamento atesta que a Universidade de São Paulo não está simplesmente atrasada ou sendo omissa, mas realizando um esforço efetivo de manter uma política anti-cotas, ignorando debates e demandas realizadas dentro e fora de seus muros que defendem a democratização do Ensino Superior desde o processo de redemocratização do país. Desconsiderar o pronunciamento favorável do Supremo Tribunal Federal à constitucionalidade da adoção de políticas de cotas nas universidades brasileiras, ocorrido em 2012, a Lei de Cotas, aprovada nesse mesmo ano, e a Portaria Normativa n. 13, publicada pelo Ministério da Educação (MEC) em maio de $2016^{16}$ e que dispõe sobre a indução de ações afirmativas na Pós-Graduação, coloca a USP em situação de inconstitucionalidade. Em resumo, este arquivamento apenas demonstra o quanto nossa universidade tem se recusado em atualizar suas instâncias de processos decisórios para formas mais participativas e democráticas, alinhadas às diretrizes e leis da Constituição Federal de 1988, e em particular, de renunciar ao caráter de formação e reprodução de elites, que marcou sua criação na década de 1930, para se tornar efetivamente uma instituição de formação de profissionais e produção de conhecimentos plurais que constituem a sociedade brasileira.

\section{COTAS RACIAIS E O RECONHECIMENTO PÚBLICO DAS DIFERENÇAS}

O Brasil tem recursos naturais mas passa fome, é naturalmente rico mas vive endividado, é negro e mestiço mas deseja ser europeu.

Abdias do Nascimento

Um processo seletivo que contemple uma política de ações afirmativas deve considerar, em primeiro lugar, as diferenças de trajetória social e de formação
15 Que afirma: "Cabe a cada Programa de Pós-Graduação elaborar seu regulamento e normas, que deverão ser aprovados pela CPG responsável pelo Programa, com as particularidades de sua área, respeitando o estabelecido pela CPG e CoPGr em suas decisões, normas, Regimentos e Regulamentos". Disponível em: http://www.leginf.usp. $\mathrm{br} /$ ?resolucao=resolucao-no6542-de-18-de-abril-de-2013. último acesso em 15/02/17. Pós-Graduação, e dá outras providências. Publicada em 11 de maio de 2016. Disponível online em: http://www.faders. rs.gov.br/legislacao/4/517. Último acesso em 15/02/2017. 
entre os grupos alvos a serem alcançados por ela. No caso do PPGAS, foi consenso o entendimento de quais categorias de pessoas permaneciam em plena invisibilidade nos espaços de produção da disciplina antropológica e qual seria a melhor medida de acesso a esses espaços. Houve uma decisão coletiva de optar na proposta de cotas por um sistema de reserva de $20 \%$ do total das vagas para mestrado e para o doutorado abertas em edital para pessoas negras e de $5 \%$ para pessoas com deficiência; para pessoas indígenas a proposta pretendia criar 2 vagas como cota fixa ${ }^{17}$. Esse desenho demanda a realização de dois processos seletivos. Um de caráter regular, contendo reserva de vagas para candidatas/os autodeclaradas/os pretas/os e pardas/os e pessoas com deficiência. Outro, direcionado exclusivamente para candidatas/os autodeclaradas/os indígenas. Para além das categorias descritas no projeto que tramitou na universidade, também se reconhece a necessidade de inclusão de outros grupos invisibilizados, como pessoas trans e quilombolas.

Cabe ressaltar que uma política eficaz de ações afirmativas não deve limitar-se às adequações no processo seletivo para o ingresso de um perfil específico de candidatas/os. Antes, ela requer um conjunto de ações que precisam estar organizadas num programa consistente de arregimentação e habilitação de candidata/o, algo que antecede os procedimentos de ingresso ao Programa e que deve ser contínuo a cada novo processo. Como não se finda em si mesma, uma política afirmativa de cotas deve estabelecer formas de acompanhamento de ingressantes, implementando políticas de bolsas segundo critérios socioeconômicos, formando comissões de avaliação periódica e de apoio acadêmico e institucional, em um diálogo constante e próximo com estudantes cotistas. Nestes termos, propusemos que a avaliação das mudanças no processo seletivo ocorresse considerando a necessidade de discussões futuras e contínuas sobre a implementação destas etapas.

Repensar as tecnologias de acesso aos Programas de Pós-graduação de uma forma geral, e ao PPCAS de maneira mais singular, nos impeliu a pensar quem de fato era abarcado pelo modelo recorrente de seleção que, como está hoje, é baseado, sobretudo, na avaliação precoce de proficiência em línguas estrangeiras. $O$ acesso a um aprendizado de qualidade de uma segunda ou terceira língua está circunscrito a uma porcentagem da população que, além de pertencer a um universo cujos padrões sócio-econômicos são bastante distintos em relação a grande parte das/os brasileiras/os, também corresponde a um perfil racial específico, ou seja, são pessoas majoritariamente brancas. Na produção da proposta e na fundamentação de uma justificativa pública acerca das categorias de pessoas as quais a política abrangeria foi imprescindível recuperar uma produção sócio-antropológica que demonstrasse algumas das ações institucionais e alguns dispositivos históricos de exclusão das pessoas não brancas. Assim, é impossível pensar
17 A escolha pela fixação de uma cota (adicional às vagas existentes) se apoia no fato de ser um público específico, e a quantidade sugerida de 02 vagas anuais (para Mestrado e Doutorado) foi baseada em experiências de outros programas que adotaram ações afirmativas para esse público, por se tratar de candidatas/ os que podem exigir alguma atenção especial do programa. 
ações afirmativas sem reconhecer o protagonismo dos movimentos negros, como importantes atores para se pensar as dimensões sociais do conceito de raça bem como algumas de suas formas de apreensão (Munanga, 2006).

Segundo Munanga, a dimensão social do conceito de raça emerge com força no cenário político brasileiro com alguns movimentos culturais teatrais que recuperam a categoria "negro", em cumplicidade à luta por direitos civis estadunidense que atribuiu à categoria "black" um conceito identitário (Munanga, 2014:39). Portanto, assim como nos Estados Unidos, no Brasil o debate público acerca dos direitos civis para pessoas negras passa a ser usado quase como um sinônimo da ideia de identidade, aproximando-se do conceito de etnia (Fassin, 2006; Munanga, 2006).

O interesse do Estado em pensar ações afirmativas de ingresso ao Ensino Superior se deu no século XXI. Em 2001, ocorreu em Durban, na África do Sul, a Terceira Conferência Mundial da ONU contra o Racismo, a Discriminação Racial, a Xenofobia e a Intolerância Correlata, cujas pautas mais importantes apresentavam a necessidade de se ampliar políticas afirmativas de acesso educacional à população negra da diáspora. Nessa ocasião, o Brasil, que estava entre os países que mais recebeu pessoas escravizadas, bem como entre aqueles que por mais tempo sustentou uma economia escravocrata, assinou um compromisso internacional para constituir tecnologias estatais protecionistas e reparadoras tanto para sua extensa população negra, como para outras minorias sociais (Munanga, 2014).

As primeiras políticas de cotas adotadas para as Instituições de Ensino Superior emergiram nos anos seguintes. A Universidade Estadual do Rio de Janeiro (UERJ) foi pioneira, seguida de início por algumas universidades estaduais e posteriormente por universidades federais. Tais projetos respondiam a uma demanda antiga dos movimentos negros, bem como de uma produção intelectual preocupada em tornar públicos os dispositivos históricos de exclusão da população negra nos espaços de produção do saber.

O processo inicial de adoção das cotas raciais em algumas instituições de ensino e da ampliação da política de modo a atingir o maior número possível de universidades brasileiras contou com a participação de três segmentos: ativistas da sociedade civil, pesquisadoras/es e intelectuais e gestoras/es públicas/os vindas/os das cátedras universitárias. Este processo constatou o caráter de urgência de ações para elevar a presença de negras e negros nas universidades, de modo a se aproximar de um índice de representatividade populacional (Cuimarães e Rios, 2014).

Com a Lei de Cotas e a obrigatoriedade de políticas inclusivas em todas as instituições federais de Ensino Superior, o perfil racial de estudantes nas universidades públicas sofreu uma alteração significativa, conseguindo em algumas 
carreiras melhorar os índices de representatividade da população negra. Porém, atualmente é possível constatar que esta alteração não produziu mudanças no perfil racial de ingressantes nos cursos de pós-graduação, motivo pelo qual criou-se a Portaria Normativa ${ }^{0} 13 / 2016$ assinada pelo Ministro da Educação no governo Dilma Rousseff que regulamenta a obrigatoriedade das ações afirmativas junto aos Programas de Pós-Graduação.

A ausência de negras e negros nos cursos de pós-graduação também é uma evidência na USP, perceptível mesmo diante do fato da universidade não produzir ou publicizar qualquer mecanismo de coleta e de averiguação desse dado. Podemos levantar como hipótese que, se a porcentagem de estudantes negros na graduação já é pequena, na pós-graduação a representatividade negra há de ser ainda menor. É exatamente este cenário que nossa proposta pretende mudar.

\section{A ESPECIFICIDADE DOS POVOS INDÍGENAS NA PÓS-GRADUAÇÃo}

Por séculos, a implementação de escolas voltadas aos povos indígenas foi orientada para projetos coloniais de controle territorial e obtenção de mão de obra. Ainda no século XX, sob os ideais de integracionismo e assimilacionismo e um gradiente que classificava povos indígenas em termos de contato e "civilização", o propósito da escolarização-seja oferecida por ordens religiosas, seja pelo Serviço de Proteção ao Índio (SPI), posteriormente Fundação Nacional do Índio (Funai) - fora, sobretudo, transformar as/os índias/os em trabalhadoras/es rurais, integrando-as/os à sociedade nacional.

Paradoxalmente, as consequências de tal escolarização serviram também para que as populações indígenas obtivessem novas ferramentas para articular suas demandas e lutar por seus direitos, buscando ser reconhecidas como cidadãs plenas de direito. O movimento indigenista e indígena como um todo, e em particular as organizações de docentes indígenas que emergiam nos anos 1980 , foram atores chave para a redação dos artigos referentes aos seus direitos na Constituição Federal de 1988, incluindo-se o Art. 210, parágrafo $2^{\circ}$, que trata da educação escolar indígena, assegurando que: "O ensino fundamental regular será ministrado em língua portuguesa, assegurada às comunidades indígenas também a utilização de suas línguas maternas e processos próprios de aprendizagem".

Colocar isso em prática ainda se apresenta como um grande desafio - o que não impede, contudo, que a escola tenha se tornado uma realidade em quase todos os grupos indígenas no Brasil (Grupioni, 2008). A partir da mudança constitucional do paradigma da educação escolar indígena, houve reorganização administrativa e expansão do sistema de ensino em terras indígenas e, consequentemente, a necessidade de formação de docentes indígenas e o desenvol- 
vimento de propostas curriculares para uma educação "intercultural, bilíngue, específica e diferenciada".

No contexto escolar, a mediação entre formas de conhecimento está sujeita às constrições de uma instituição que é estranha às formas de organização indígenas e, ao mesmo tempo, central para a constituição do Estado moderno (Cavalcanti-Schiel, 2007). A escola na aldeia é um aparato estatal que fornece uma gramática de acesso para diferentes esferas reivindicatórias, por meio do letramento e dos currículos escolares, mas também da socialização em uma instituição não-indígena com lógicas disciplinares, burocratizadas, classificatórias, individualizadoras, hierarquizadoras. Desse modo, a presença da escola e a experiência da escolarização se entremeiam aos modos de organização indígenas, entre eles, do movimento indígena, ainda que de modo reflexivo.

Este quadro tem reiterado concepções de cultura e conhecimento como uma organização mais ou menos sistemática de traços e conteúdos. Da mesma forma, a expectativa de que a formação de docentes indígenas implica necessariamente transformá-las/os em pesquisadoras/es de sua própria cultura, a fim de que possam ensiná-la no ambiente escolar para suas/seus alunas/os e produzir materiais didáticos que preservem uma cultura evanescente, torna-as/os agentes de uma noção de cultura como um repositório de informações necessárias para ser membro de um enclave (Strathern, 1987: 154-157), focando-se mais nos produtos que nos processos de aprendizado.

Não obstante, o acesso de estudantes indígenas ao Ensino Superior nos cursos de graduação tem crescido e tornou-se recentemente uma potente demanda do movimento indígena. Com exceção de casos isolados que ocorreram há mais tempo, sobretudo de estudantes provenientes de internatos confessionais que se formaram em teologia e filosofia, a presença indígena nas universidades tem início há pouco mais de uma década. Ela é fruto, majoritariamente, de dois movimentos paralelos. Em primeiro lugar, a expansão do Ensino Médio, que, nas escolas indígenas, gera tanto a necessidade de formação de docentes indígenas em licenciaturas para atuarem nesse nível de ensino, como amplia a demanda de estudantes indígenas egressas/os do Ensino Médio pela continuidade de seus estudos no Ensino Superior. Ou seja, é um movimento que se retroalimenta. Em segundo lugar, a ampliação das ações afirmativas nas universidades públicas brasileiras tem criado mecanismos de acesso e permanência para estudantes indígenas no esteio de políticas para outras populações. Ambos os fatores são impactados pela expansão e interiorização do Ensino Superior público e privado ocorridas no Brasil nos últimos 15 anos.

As duas modalidades em que estudantes indígenas têm ingressado no Ensino Superior são os cursos regulares oferecidos pela instituição, por meio 
de "cotas" (reserva ou criação de vagas específicas), ou nas licenciaturas específicas. Entre as experiências pioneiras dos anos 2000, podemos citar a criação de vagas para estudantes indígenas nas universidades estaduais do Paraná e a criação do curso Terceiro Crau Indígena na Universidade Estadual do Mato Grosso (Unemat) em 2001, o convênio entre a Universidade de Brasília (UnB) e a Funai, firmado em 2004, e os editais do Programa de Apoio à Formação Superior e Licenciaturas Indígenas (Prolind), do Ministério da Educação (MEC), editados em 2005, 2008 e 2009, que engendraram diversas experiências por todo o país, incluindo a Universidade de São Paulo.

Após uma década de início dessas experiências, a promulgação da chamada Lei de Cotas (Lei 12.711/2012) alterou boa parte dos arranjos sobre cotas no Brasil. Se, por um lado, esta lei propõe ampliar por todo o país o acesso de estudantes indígenas ao Ensino Superior, por outro lado, faz com que arranjos construídos em diálogos com as populações locais sejam abandonados pelo estabelecimento de um modelo generalizado para o Brasil. Outro aspecto controverso da lei é que ela estabelece mecanismos indiferenciados de reserva de vagas para estudantes pretas/os, pardas/os e indígenas (em muitos casos reunidos pela sigla PPI), distinguindo-as/os apenas na porcentagem da reserva, relativa à proporção dessas populações em cada unidade da federação. Tratar o acesso de estudantes indígenas como o de outras "minorias" tem o intuito de defender a igualdade de acesso a um direito, sem considerar que ele tem sido desigualmente alcançado e sem reconhecer as especificidades dos povos indígenas e todo o histórico de construção do debate a respeito da educação escolar indígena diferenciada e das propostas de interculturalidade. Isso tem sido motivo de forte crítica pelo movimento indígena, por indígenas e não-indígenas ligados ao tema. Os diferentes modos de organização social e escolarização indígenas, brevemente descritos acima, colocam demandas e necessidades para estudantes indígenas que são diferentes daquelas de estudantes negras/os, submetidas/ os a formas outras de marginalização. Invisibilizar suas presenças e demandas específicas representa um retrocesso para as conquistas de direitos recentemente alcançados nesse âmbito.

Apesar desses entraves, há um contingente de estudantes indígenas formado em cursos regulares de graduação e nas licenciaturas que, por sua vez, passa a gerar pressão para seu ingresso na pós-graduação, seja em especializações lato sensu (muitas delas voltadas às áreas de educação e saúde), seja em mestrados e doutorados. Embora sua presença na pós-graduação possa reproduzir a captura da sistematização de saberes indígenas em recortes disciplinares ocidentais, a formação de pesquisadoras/es indígenas pós-graduandas/os desponta-se como uma oportunidade ímpar para a ampliação de repertórios conceituais e metodológicos, ampliando os cânones disciplinares e permitindo a formulação 
de novas agendas, novas questões e novas relações entre a universidade, seus campos de pesquisa e os povos indígenas. Trata-se, também, de um modo político de ocupar espaços e ampliar relações, de abertura para as multiplicidades de epistemologias também nos quadros discentes. E, nunca é demais ressaltar, a pós-graduação é responsável por uma parcela considerável da produção científica brasileira.

Contudo, quando se defende a formação de pesquisadoras/es indígenas é preciso contextualizar os muitos pressupostos por trás dos usos de "cultura" em jogo, atentando para o fato de que a sistematização de conhecimentos e práticas indígenas tem sido capitaneada por especialistas universitárias/os a partir de seus recortes disciplinares, sob a égide de promover o reconhecimento desses saberes. Isto acarreta, muitas vezes, no desmembramento dos sistemas indígenas em "etno-disciplinas" e, consequentemente, dos modos como estes saberes são articulados no contexto das aldeias. Para a antropologia e para as/ os indígenas, a experiência de pesquisadoras/es indígenas na pós-graduação constitui um experimento, no sentido forte da expressão. Por ser uma área do conhecimento interessada em modos outros de produção, sistematização e circulação de conhecimentos e relações sociais, a antropologia abre a possibilidade de experimentar e renovar conceitos, análises e metodologias de investigação, a partir de um diálogo que preserve as especificidades e objetivos desses diferentes saberes, de modo proveitoso tanto para as universidades quanto para os diferentes coletivos indígenas.

\section{BARREIRAS NA PÓS-GRADUAÇÃO: ONDE ESTÁ A DEFICIÊNCIA?}

O acesso à Educação Superior em igualdade de oportunidades e condições com as demais pessoas é um dos preceitos da chamada Lei Brasileira de Inclusão's, a qual regulamenta parcialmente a Convenção Internacional dos Direitos da Pessoa com Deficiência. Esta última, por sua vez, foi ratificada no Brasil como Emenda Constitucional no ano de 2009 (Decreto Federal n 6.949/09), quando foi determinada a implementação de políticas para assegurar o acesso a um sistema educacional inclusivo em todos os níveis.

Desde a década de 1980, pelo menos, marcos legais nacionais e internacionais relativos a pessoas com deficiência evidenciam uma preocupação considerável do poder público com a inclusão de tais sujeitos nas mais diversas esferas da vida social. Esse percurso temporal é bastante pautado por um movimento social amplo e tem um dos seus desfechos fundamentais na Lei Federal 10.098/00, que estabelece normas gerais e critérios básicos para a promoção de acessibilidade de pessoas com deficiência ou com mobilidade reduzida. Além de versarem sobre as estruturas de espaços públicos em geral, é possível dizer (resumindo

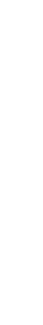


bastante) que esse texto legislativo e suas regulamentações subsequentes obrigaram também as universidades de todo o país a reorganizarem suas estruturas com o intuito de receberem estudantes também com deficiência.

No caso da USP, a Portaria GR 3304 do ano de $2001^{19}$ oficializou a criação de uma comissão permanente com fins de elaboração de políticas para a inserção das pessoas com deficiência no ambiente da Universidade. Em 2011, tal Comissão tornou-se um programa regular denominado USP Legal, sob a responsabilidade da Pró-Reitoria de Cultura e Extensão Universitária, por meio da Resolução 5971/2011. Conforme dados oficiais divulgados por instâncias da Universidade ${ }^{20}$, esse Programa atua em cinco frentes, por meio de docentes e gestoras/es, que promovem ações no dia a dia, sendo objetivo da Coordenadoria transformar tais ações em políticas.

$\mathrm{Na} \mathrm{FFLCH}$, durante os últimos anos, foram amplamente notadas algumas adaptações, como a criação de banheiros para pessoas com mobilidade reduzida e, sobretudo, nas dependências externas dos prédios, a instalação de rampas. Ao incorporarmos pessoas com deficiência entre as/os contempladas/os pela proposta de ações afirmativas na pós-graduação, notou-se, entretanto, a necessidade de maior esclarecimento e debate acerca do tema.

Em primeiro lugar, dados acerca do número de graduandas/os e pós-graduadas/os com deficiência matriculadas/os na USP em geral ainda estão bem pouco sistematizados ou não são amplamente divulgados. Conforme matéria publicada no Jornal da USP no final de $2013^{21}$, o Programa USP Legal estimava naquele momento a presença de cerca de 200 alunas/os com deficiência na graduação, indicando, contudo, a possibilidade de um número maior sob alegação de que poucas vezes as/os estudantes declaram tal condição. Afirma-se, ainda, na mesma matéria, que no caso da pós-graduação os dados não estão quantificados.

Ao buscarmos informações acerca da presença de pessoas com deficiência na FFLCH, soubemos da existência de uma Comissão de Acessibilidade própria da faculdade, responsável pela implementação de um programa análogo e complementar ao USP Legal e criado pela Portaria 007/2009, de 16 de fevereiro de $2009^{22}$.

Ao procurarmos a Comissão de Acessibilidade da FFLCH, constatamos que, de fato, analogamente ao USP Legal, a Comissão de Acessibilidade realizava um "trabalho de formiguinha": a existência de uma lupa eletrônica foi apontada como recurso disponível frente à presença de estudantes com deficiência visual e tarefas tais como a digitação de provas foram ocasionalmente incorporadas ao cotidiano dos departamentos.

Um argumento bastante recorrente apresentado acerca da pouca sistematização sob um conjunto que conformasse uma ampla política de acessibilidade na FFLCH foi o fato de não haver uma presença massiva de estudantes com de-
19 Disponível em:http://www.leginf.usp. $\mathrm{br} /$ ?portaria=portaria-grno-3304-de-10-de-outubrode-2001, acesso em 10 de março de 2017.

20 Disponível em:http:// www5.usp.br/37627/usp-legalajuda-a-superar-barreirasimpostas-as-pessoas-comdeficiencia/, acesso em 10 de março de 2017.

21 Disponível em:http:// www5.usp.br/37627/usp-legalajuda-a-superar-barreirasimpostas-as-pessoas-comdeficiencia/, acesso em 10 de março de 2017.

22 Disponível em: http:// acessibilidade.fflch.usp.br/sites/ acessibilidade.fflch.usp.br/files/ portaria_acessibilidade_o.pdf, acesso em 10 de março de 2017. 
ficiência matriculadas/os - tanto na graduação quanto na pós-graduação-que demandasse recursos e reestruturações. Diante desse quadro, compreendemos que o desincentivo ou resistência às ações afirmativas na universidade apenas contribuem para reproduzir o que na realidade se trata de um círculo vicioso: afirma-se que a FFLCH não oferece todas as condições porque estudantes com deficiência não ingressaram até então, mas se a universidade não oferecer condições, tais estudantes não terão como ingressar.

Decidimos então organizar uma mesa sobre o tema. De maneira diferente ao que ocorre no caso de populações indígenas e negras, a ausência de uma tradição de estudos sobre deficiência na Antropologia contou como mais um dos fatores relevantes para a necessidade de fomentar o debate e o esclarecimento no interior da faculdade. Assim, no dia 14 de março de 2014 foi realizado no prédio das Ciências Sociais/FFLCH o evento "Deficiência na/da Pós-Graduação", que contou com a presença das/os convidadas/os: Profa Débora Diniz (UnB), Adriana Dias (ABA), Ana Rita de Paula (IP/USP) e Prof. Pablo Mariconda (FFLCH-USP). Renomadas/os intelectuais da área, bem como militantes e representantes de órgãos relativos à pessoa com deficiência ou à Antropologia, puderam agregar importantes considerações ao debate e contribuíram para que a proposta de cotas fosse refinada.

As discussões realizadas nesse dia contribuíram também para o esclarecimento, de maneira mais ampla, acerca de questões conceituais, históricas e sociológicas sobre a real necessidade de uma política de cotas para pessoas com deficiência no âmbito da pós-graduação e sobre as demandas colocadas por estudantes com deficiência, considerando seus direitos garantidos juridicamente e os exemplos das atuais políticas de inclusão, implantadas desde 2014 em outras instituições universitárias.

Dois pontos são imprescindíveis para pensar políticas de inclusão para pessoas com deficiência no ambiente universitário: a revisão das questões históricas que marginalizaram e excluíram por muito tempo esses sujeitos, privando-os também do ponto de vista educacional; a reorganização não somente de espaços arquitetônicos, meios tecnológicos e de comunicação, mas também a reformulação das concepções para a mudança de atitudes frente às pessoas com deficiência.

Conforme demonstra uma ampla bibliografia da área, os pressupostos de que a deficiência seria uma desvantagem do ponto de vista individual e estritamente localizada no corpo biológico implicaram processos de exclusão e marginalização nas mais diversas esferas da vida social. Pessoas com deficiência foram por muito tempo consideradas inferiores em suas habilidades ou incapazes de frequentar ambientes escolares em condições de igualdade, tendo sido, assim, privadas do direito à educação. Contudo, as conjecturas que atribuíram 
menor valor às pessoas com deficiência passaram a ser questionadas de um ponto de vista sociológico e, à medida que a desigualdade atribuída a corpos com certas variações de funcionamento foi deslocada para a estrutura social, a deficiência passou a ser vista como uma desvantagem derivada não de configurações corporais, mas de ambientes opressivos.

Ao menos desde a década de 1950, a compreensão da deficiência vem sendo questionada e revista, o que se deve em grande medida aos debates de movimentos intelectuais e políticos protagonizados por pessoas com deficiência, outrora largamente invisibilizadas. Atualmente, entende-se que a deficiência não é uma sentença da natureza, mas o resultado de um movimento discursivo da cultura da normalidade, a qual descreve impedimentos corporais como abjetos à vida social (Diniz, Barbosa e Santos, 2009).

Essa mudança de paradigma foi fundamental para o reconhecimento da deficiência como uma questão de direitos humanos e para a progressiva formulação de políticas de inclusão voltadas ao segmento em questão. As políticas de acessibilidade desenvolvidas e regulamentadas no Brasil promovem os conceitos relacionados aos aspectos sociais da deficiência e atualmente compreende-se que esta resulta da interação entre as pessoas com deficiência e as barreiras devidas às atitudes e ao ambiente, que impedem a plena e efetiva participação na sociedade em igualdade de oportunidades com as demais pessoas. Cabe ao poder público elaborar políticas para eliminação dessas barreiras.

Das barreiras físicas ou arquitetônicas, comunicacionais e atitudinais em relação às quais a legislação brasileira estabelece critérios e normas de acessibilidade, sem dúvida o enfrentamento da barreira atitudinal é um desafio maior para o ingresso nos cursos de pós-graduação. Para tanto, encarar a deficiência como uma questão de desvantagem social é imprescindível para que de fato pessoas com deficiência possam ser incluídas.

Em consonância com essa perspectiva, recentemente foi apresentada $e$ aprovada uma moção da $\mathrm{ABA}^{23}$ no $39^{\circ}$ Encontro Anual da ANPOCS, em 2015, aos cursos de pós-graduação em Ciências Sociais pontuando "o abismo que ainda separa pessoas com deficiência da possibilidade de cursar graduação e pós-graduação" e recomendando que sejam estabelecidas cotas para pessoas com deficiência pautando-se na Classificação de Funcionalidade, Incapacidade e Saúde (CIF) e não na Classificação Internacional das Doenças e Problemas relacionados com a Saúde (CID). Recomendou-se também a criação de comitês de acessibilidade para garantia de direitos e viabilização de estratégias de permanência dessas/es estudantes, como parte da estrutura de programas de pós-graduação e associações científicas, algo já estabelecido na ABA desde o ano de 2012.
23 Moção aos Cursos de Graduação e Pós-Graduação em Ciências Sociais, disponível online: http://www.portal. abant.org.br/images/Noticias/ Mo\% $3 \%$ A7\% 3 С $\%$ А PessoasComDefici\% $3 \%$ A AnciaANPOCS.pdf, acesso em 10 de março de 2017. 


\section{CONTINUIDADES E TRANSFORMAÇÕES}

Seguindo percurso semelhante ao desenvolvimento do acesso para pessoas com deficiência, as discussões referentes a pessoas trans também são fruto de uma crescente militância e uma movimentação recente. No caso de nossa proposta, sua formulação em 2013 previa a incorporação de pessoas trans ao longo de sua implementação, embora não tivéssemos precisado se ela ocorreria por reserva de vagas (tal como consta para pessoas autodeclaradas pretas e pardas e pessoas com deficiência) ou criação de vagas adicionais (tal como prevemos para indígenas). A discussão sobre pessoas trans deve ser impulsionada futuramente, assim como a referente à identidade política quilombola, contemplando as diversas trajetórias e ponderando quais as específicas dificuldades de acesso, que demandam políticas afirmativas compatíveis.

Desde 2013, felizmente, vêm aumentando tanto as discussões sobre gênero, quanto a visibilidade e o acesso de pessoas trans nos espaços educacionais. As vivências de pessoas trans apontam justamente para como gênero - entendido como forma de classificar o que é considerado masculino e o que é considerado feminino - compõe um sistema reproduzido o tempo todo, organizando e moldando regras em nossas relações (Scott, 1989). Além de uma divisão binária excludente (ou se é homem ou se é mulher), há uma suposição de que os gêneros dependem de corpos sexuados (homem porque nasceu com um pênis e muIher porque nasceu com uma vagina). Pessoas trans, que vivem um gênero que não aquele que lhes foi atribuído em seu nascimento, estipulado externamente apenas a partir de seu sexo dito biológico, descrevem experiências violentas em ambientes familiares, educacionais e profissionais. As violências ocorrem continuamente pelo não reconhecimento de que sejam pessoas normais (tanto que transexualidade ainda consta em manuais internacionais como uma doença, como no caso do CID, ou do DSM), e são sentidas por não se enquadrarem às normas legitimadas de gênero, gerando expulsão de suas casas de origem, alto índice de evasão escolar e ulteriores condições precárias de trabalho.

Por estes motivos, faz-se necessário repensar também as formas de acesso de pessoas trans na graduação e pós-graduação através de ações afirmativas que garantam também sua permanência com respeito às suas variadas e específicas vivências, incluindo possibilidades de autoidentificação como homens trans, mulheres trans, travestis, pessoas não-binárias e intersex. Nesse sentido, foi efetivada a Resolução Federal $n^{\circ}$ 12, de 16 de janeiro de 2015, que "estabelece parâmetros para a garantia das condições de acesso e permanência de pessoas travestis e transexuais - e todas aquelas que tenham sua identidade de gênero não reconhecida em diferentes espaços sociais - nos sistemas e instituições de ensino, formulando orientações quanto ao reconhecimento institucional da 
identidade de gênero e sua operacionalização"24. Tal reconhecimento institucional dispõe acerca do uso de banheiros, que devem seguir a autoidentificação de gênero de pessoas trans, e toda aceitação da comunidade acadêmica diante do reconhecimento do Nome Social, diverso do que consta em registros civis, exigindo alteração nos habituais documentos e procedimentos acadêmicos.

A questão da educação escolar quilombola encontra certos paralelos em relação às mencionadas a respeito da educação escolar indígena, no sentido de ser uma educação direcionada a comunidades que vivem outras formas de organização social, que demandam uma educação específica e diferenciada, não idêntica à educação no campo ou a formas de ações afirmativas destinadas a populações negras urbanas. O trânsito institucional entre o MEC, o Incra e outros órgãos do governo incumbidos de desenvolver políticas voltadas a quilombolas, somados ao binômio fuga e resistência, que ainda constitui o imaginário sobre o que é ser quilombola no Brasil, tem invisibilizado as diferentes formas pelas quais estas comunidades se mantêm e as questões que trazem. A antropologia tem uma trajetória longa de pesquisas com comunidades quilombolas e tem sido solicitada como perita em questões de titulação de terras e patrimonialização, contudo, ainda é reduzida a presença de quilombolas nos espaços de formação antropológica.

Quanto a mecanismos que auxiliem a permanência de alunas/os cotistas no PPCAS/USP, em nossas discussões foram levantadas inúmeras formas de incentivar e informar acerca de cursos de escrita antropológica e de línguas estrangeiras (obrigatoriamente exigidas ao longo das formações) que já são ofertados gratuitamente na universidade. Ademais, além de alterações dos espaços físicos, devem-se levar em conta as condições materiais de permanência, tais quais bolsas de estudo. Esse aspecto constitui um acirrado debate, diante da atual (e cada vez mais) escassa oferta de bolsas, o que condiciona o número de ingressantes nos programas de pós-graduação. Diante desta situação, surgem mais embates quanto à distribuição de bolsas seguindo o atual critério meritocrático de ordem na lista de aprovação no processo seletivo, ou uma forma a ser melhor elaborada em nossa proposta, que siga critérios socioeconômicos. Tais critérios recolocam perguntas: quem deve prioritariamente receber bolsa? Sua distribuição deve ser atrelada ao ingresso das pessoas que entrariam por ações afirmativas?

Estas perguntas nos desafiam a continuar pensando e nos mobilizando na implementação de ações afirmativas que cada vez mais contemplem a atenção ao acesso, à permanência e às mudanças das relações e das produções nas universidades. Cabe reforçar que as ações que se desenharam neste artigo visam ser temporárias e acompanhadas por uma comissão responsável pela paulatina implementação e ulterior retirada destas. Como salientado desde o início, mais que preocupação com a integração e adaptação dos processos seletivos para que
24 Disponível em:https:// www.defensoria.sp.def. br/dpesp/Repositorio/39/ Documentos/Resolucao\%20 $12 \% 202015 \% 20-\% 20$ Conselho\%20LCBT\%20 da\%20Secretaria\%20de\%20 Direitos\%20Humanos\%20 da\%20Presid\%C3\%AAncia\%20 \%20-\%20Nome\%20social\%20 e\%20uso\%2ode\%20 banheiro\%2onas\%2oescolas. pdf, acesso em 10 de março de 2017. 
as pessoas consigam acessar a universidade, pretendemos transformar a universidade, impulsionando a pluralidade nas formas de habitá-la e de construir novos conhecimentos.

A Comissão de Cotas e Ações Afirmativas do PPGAS-USP tem trabalhado ininterruptamente desde 2013 para consolidar uma proposta de cotas que tenha impactos relevantes no perfil discente e na produção de conhecimento da universidade. Nossos esforços contagiaram outros programas dentro e fora da universidade, desmistificando preconceitos e temores em relação às ações afirmativas e construindo reflexões a partir das experiências existentes. Acreditamos que a universidade é um contínuo fazer, que exige cada vez mais instâncias democráticas de participação para que suas atividades sirvam verdadeiramente à função social de formar pessoas e produzir conhecimentos que construam uma sociedade mais digna e justa.

Ana Letícia de Fiori é doutoranda do PPCAS/USP, pesquisadora do Laboratório do Núcleo de Antropologia Urbana, do Centro de Estudos Ameríndios-CEstA/ USP, do Núcleo de Antropologia do Direito - NADIR/USP e integra a Comissão Permanente de Ações Afirmativas (CPAA) do Programa. Realiza atualmente pesquisas na área de Etnologia Urbana, com os seguintes temas: estudantes indígenas na universidade, interculturalidade, ensino superior e política, circuitos indígenas no Amazonas.

Cibele Barbalho Assênsio é Mestra em Antropologia Social (PPCAS/USP), pesquisadora do Laboratório do Núcleo de Antropologia Urbana da USP (LabNAU/ USP) vinculada ao COCCIX - Estudos de Corpo e Cidade e ao Grupo de Estudos Surdos e da Deficiência (CESD) desse laboratório. Também integra a Comissão Permanente de Ações Afirmativas (CPAA) do Programa. Realiza atualmente pesquisas sobre os temas surdez e a Língua Brasileira de Sinais (LIBRAS), lideranças surdas e corporalidades.

Fabiana de Andrade é doutoranda do PPCAS/USP, integrante do HYBRIS (Crupo de Estudo e Pesquisa sobre Relações de Poder, Conflitos, Socialidades) e da Comissão Permanente de Ações Afirmativas (CPAA) do Programa. Realiza pesquisa na intersecção entre políticas públicas e violência doméstica e familiar contra a mulher, inserida nas áreas de antropóloga de gênero e antropologia das emoções. 
Jacqueline Moraes Teixeira é doutoranda do PPGAS/USP, pesquisadora do Laboratório do Núcleo de Antropologia Urbana da USP (Lab/NAU) e do Centro Brasileiro de Análise e Planejamento (CEBRAP). Também integra a Comissão Permanente de Ações Afirmativas (CPAA) do PPGAS/USP. Realiza pesquisas nas áreas de antropologia urbana, antropologia da religião e dos marcadores sociais da diferença.

Letizia Patriarca é doutoranda do PPCAS/USP, integrante do Núcleo de Estudos dos Marcadores Sociais da Diferença (NUMAS) da FFLCH-USP e da Comissão Permanente de Ações Afirmativas (CPAA) do Programa. Possui particular interesse nas Áreas: Gênero e Sexualidade, Unidades Prisionais, Marcadores Sociais da Diferença, Queer e Antropologia Urbana.

Talita Lazarin Dal Bo é doutoranda do PPCAS/USP, pesquisadora do Centro de Estudos Ameríndios - CEstA/USP e integra a Comissão Permanente de Ações Afirmativas (CPAA) do Programa. Realiza pesquisas na área de Etnologia Indígena, principalmente com os seguintes temas: modos de saber indígenas, estudantes indígenas na universidade, conhecimento tradicional, antropologias indígenas.

\section{REFERÊNCIAS BIBLIOGRÁFICAS}

BRASIL

Decreto Federal $n^{0}$ 6949, de 25 de agosto de 2009. Promulga a Convenção Internacional sobre os Direitos das Pessoas com Deficiência e seu Protocolo Facultativo, assinados em Nova York, em 30 de março de 2007. Disponível online em: http://www.planalto.gov.br/ccivil_03/_Ato2007-2010/2009/ Decreto/D6949.htm . Último acesso em 17 fev/2017.

Lei Federal $n^{0} 12.711$, de 29 de agosto de 2012. Dispõe sobre o ingresso nas universidades federais e nas instituições federais de ensino técnico de nível médio e dá outras providências. Disponível online em: http://www.planalto. gov.br/ccivil_03/_ato2011-2014/2012/Lei/L12711.htm. Último acesso em $17 / 02 / 17$.

Lei Federal $n^{0} 13.409$, de 28 de dezembro de 2016. Dispõe sobre a reserva de vagas para pessoas com deficiência nos cursos técnico de nível médio e superior das instituições federais de ensino. Disponível online em: http:// www.planalto.gov.br/ccivil_03/_Ato2015-2018/2016/Lei/L13409.htm\#art1. Último acesso em 17/02/17. 
Lei Federal n. 010.098, de 19 de dezembro de 2000. Estabelece normas gerais e critérios básicos para a promoção da acessibilidade das pessoas portadoras de deficiência ou com mobilidade reduzida, e dá outras providências. Disponível online em http://www.planalto.gov.br/ccivil_03/leis/L10098. htm . Último acesso em 17/02/2017.

Resolução $N^{0} 12$ de 16 de janeiro de 2015. Secretaria de Direitos Humanos. Brasília, 2015. Disponível online em: http://www.sdh.gov.br/sobre/participacao-social/cncd-lgbt/resolucoes/resolucao-012. Último acesso em 17/02/17.

CAVALCANTI-SHIEL, Ricardo

2007 "Para abordar la interculturalidade: apuntes críticos a partir de (y sobre) la nueva Educación Escolar Indígena en Sudamérica". Cahiers ALHIM.

Amérique Latine Histoire et Mémoire, 13.

DINIZ, Debora; BARBOSA, Lívia; e SANTOS, Wederson Rufino dos

2009 "Deficiência, direitos humanos e justiça". Revista Internacional de Direitos Humanos, São Paulo, v. 6, n. 11: 64-77. Disponível em: <http://www.scielo. br/pdf/sur/v6n11/04.pdf>. Último acesso em 17/02/2017.

FASSIN, Didier e FASSIN, Eric

2006 De la question sociale à la question raciale? Paris, La Découverte, 2006, p. 243-246.

GRUPIONI, Luis. D. B.

2008 Olhar longe porque o futuro é longe-Cultura, escola e professores indígenas no Brasil. São Paulo, tese, Universidade de São Paulo.

GUIMARÃES, Antonio Sérgio A. e RIOS, Flavia M.

2014 “Cotas nas universidades públicas". Afro-Ásia, n.50: 251-256.

MUNANGA, Kabengele

2014 "A questão da diversidade e da política de reconhecimento das diferenças". Crítica e Sociedade: revista de cultura política, v. 4: 34-45.

2006 'Algumas considerações sobre 'raça', ação afirmativa e identidade negra no Brasil: fundamentos antropológicos". Revista USP, v. 68: 45-57.

[OMS] Organização Mundial da Saúde

2003 CIF: Classificação Internacional de Funcionalidade, Incapacidade e Saúde [Centro Colaborador da Organização Mundial da Saúde para a Família de Classificações Internacionais, org.; coordenação da tradução Cassia Maria Buchalla]. São Paulo, Editora da Universidade de São Paulo-EDUSP. 
sobre a arte de burocratizar políticas de cotas na USP

SANTOS, Jocélio Teles dos

2012 Cotas nas universidades: análises dos processos de decisão. Salvador, Centro de Estudos Afro-Orientais da UFBA, 2012.

SCOTT, Joan

1989 Cender: A Useful Category of Historical Analyses. Cender and Politics of History. Nova York, Columbia University Press.

STRATHERN, Marilyn

2014 [1987] "Os limites da autoantropologia". In O efeito etnográfico e outros ensaios. São Paulo, Cosac e Naify, p. 133-158.

USP

Portaria de Designação Nº07/09, de 16 de fevereiro de 2009. Faculdade de Filosofia, Letras e Ciências Humanas. Disponível online em http://acessibilidade. fflch.usp.br/sites/acessibilidade.fflch.usp.br/files/portaria_acessibilidade_o.pdf Último acesso em 17/02/2017.

Portaria gr n ${ }^{\circ} 3304$, de 01 de outubro de 2001. Pró Reitoria da Universidade de São Paulo. Constitui Comissão Permanente para assuntos relativos às pessoas portadoras de deficiência vinculadas à Universidade de São Paulo. Diário Oficial do Estado de São Paulo, São Paulo, 03/10/2001.

Resolução $n^{\circ}$ 5971, de 08 de setembro de 2011. Pró Reitoria da Universidade de São Paulo. Cria o Programa USP-Legal, subordinado à Pró-Reitoria de Cultura e Extensão Universitária. Diário Oficial do Estado de São Paulo, São Paulo, 10/09/2011. 
Time and the Wind: Notes on the Art of Bureaucratize Quota Policies at USP

\section{ABSTRACT}

Why quotas in graduate studies? This article addresses this inquiry by presenting a thick description of the several bureaucratic paths fared along the implementation of an affirmative action policy. This process creates an almost unsustainable tension between the long-term temporality of the bureaucracy and the necessary winds of social change that, in this case, claim a transformation of science production technologies and the widening of legitimate environment for scientific knowledge production. This article presents the framework and the events that led to the conception and processing of a quota proposition to the Post-Graduate Program in Social Anthropology of the University of São Paulo (PPGAS/USP). Thus, we present a cartography of the quota policies among other Anthropology Post-Graduate Programs in Brazilian's current scenario. Finally, a more epistemic stance is presented in order to clarify how the widening of knowledge development environments is fundamental to bring forth plural and democratic venue in the making of anthropological knowledge.

Recebido em 18.02.2017. Aceito em 16.03.2017.

\section{KEYWORDS}

Affirmative Actions, Post-graduate quotas; University of São Paulo; Anthropology PostCraduate Programs; knowledge production. 